\title{
Recovery in Apple Trees Infected with the Apple Proliferation Phytoplasma: An Ultrastructural and Biochemical Study
}

\author{
R. Musetti, L. Sanità di Toppi, P. Ermacora, and M. A. Favali
}

First and third authors: Dipartimento di Biologia Applicata alla Difesa delle Piante, via delle Scienze, 208, 33100 Udine, Italy; and second and fourth authors: Dipartimento di Biologia Evolutiva e Funzionale, Parco Area delle Scienze, 11/A, 43100 Parma, Italy. Accepted for publication 18 September 2003.

\section{ABSTRACT}

Musetti, R., Sanità di Toppi, L., Ermacora, P., and Favali, M. A. 2004. Recovery in apple trees infected with the apple proliferation phytoplasma: An ultrastructural and biochemical study. Phytopathology 94:203-208.

Localization of hydrogen peroxide $\left(\mathrm{H}_{2} \mathrm{O}_{2}\right)$ and the roles of peroxidases, malondialdehyde, and reduced glutathione in three apple cultivars were compared in healthy trees, trees infected with apple proliferation phytoplasma (APP), and trees that had recovered from the infection. In recovered apple trees, symptoms of the disease and the pathogen had disappeared from the canopy, but phytoplasmas remained in the roots. $\mathrm{H}_{2} \mathrm{O}_{2}$ was detected cytochemically by its reaction with cerium chloride to produce electron-dense deposits of cerium perhydroxides. $\mathrm{H}_{2} \mathrm{O}_{2}$ occurred in the plasmalemma of the phloem of leaves of recovered apple trees, but not in healthy or APP-infected leaves. In all cultivars, the peroxidase activity detected in tissue from APP-diseased trees was greater than or equal to that of tissue from recovered trees, which equaled or exceeded that of tissue from healthy trees, at two sampling times (May and September). In contrast, the glutathione content of leaves decreased in the reverse order. More malondialdehyde was observed in leaves from recovered trees than in leaves from healthy or APP-infected trees in three of six cultivar-date combinations; in the other three combinations, the malondialdehyde contents of leaves from healthy, infected, and recovered trees were not significantly different from one another. The results suggest that some components of the oxidant-scavenging system in recovered leaves are not very active, leading to an overproduction of $\mathrm{H}_{2} \mathrm{O}_{2}$ and, possibly, to a membrane lipid peroxidation. The production of $\mathrm{H}_{2} \mathrm{O}_{2}$ appears to be involved in counteracting pathogen virulence.
Recovery is a spontaneous remission of symptoms in diseased plants; it may or may not involve the elimination of the pathogen from the host (25). Recovery has been reported in apple and grape affected by phytoplasmas $(11,21,26)$. The recovery of apple trees from infection by apple proliferation phytoplasma (APP) is not well known but seems to be influenced by host or pathogen genotype and environmental conditions (12).

In apple trees, recovery from APP correlates with the disappearance of phytoplasmas from the canopy but not from the roots (16). Moreover, the probability of subsequent canopy infection in these plants is about four times lower than that of plants that have not been previously infected, suggesting that induced resistance to the disease occurs (22).

We investigated the physiology of interactions between phytoplasmas and plant hosts and the recovery of APP-infected apple trees; we conducted cytochemical and biochemical studies to assess the localization of hydrogen peroxide $\left(\mathrm{H}_{2} \mathrm{O}_{2}\right)$, peroxidase activity, and amounts of proteins, glutathione, and malondialdehyde in healthy, diseased, and recovered apple trees.

$\mathrm{H}_{2} \mathrm{O}_{2}$ is a reactive compound derived from oxygen. It is produced and accumulated in cells during their interactions with pathogens (3). It has been hypothesized that $\mathrm{H}_{2} \mathrm{O}_{2}$ produced in response to pathogens, together with other molecules called reactive oxygen species (ROS), including superoxide and the hydroxyl radical, has a direct antimicrobial effect and plays a role in other defense mechanisms, including lignin production, lipid peroxidation, phytoalexin synthesis, and hypersensitive response $(13,28)$.

Corresponding author: R. Musetti; E-mail address: Rita.Musetti@uniud.it

Publication no. P-2003-1125-01R

(c) 2004 The American Phytopathological Society
It has been proposed that several metabolic systems are involved in the catalysis of ROS, including peroxidases, lipoxygenases, catalase, and the ascorbate-glutathione cycle $(4,9,27)$. These sophisticated systems mainly consists of (i) ascorbate, which can be oxidized to the monodehydroascorbate radical and dehydroascorbate, and (ii) reduced glutathione (GSH), $\gamma$-glutamyl-cysteinylglycine, which can be oxidized to glutathione disulfide (GSSG). Furthermore, plants possess enzymes directly responsible for the scavenging of oxidants, such as superoxide dismutase (EC 1.15.1.1), catalase (EC 1.11.1.6), nonspecific peroxidases (e.g., guaiacol peroxidase [GPX], EC 1.11.1.7), and specific peroxidases (ascorbate peroxidase, EC 1.11.1.11). ROS, if not detoxified by these defense metabolites and enzymes, can in turn initiate lipid (membrane) peroxidation, with the consequent biosynthesis of breakdown products, such as malondialdehyde (MDA) (7).

The aims of this study were to investigate whether the recovery phenomenon is based on overproduction of $\mathrm{H}_{2} \mathrm{O}_{2}$ to a level sufficiently high for counteracting the pathogen and, second, whether stimulation of the antioxidant defense system in recovered and APP-infected leaves can take place as a consequence of an increase in ROS formation.

\section{MATERIALS AND METHODS}

Plant material and phytoplasma detection. Apple trees of three cultivars were studied: Florina, Istrian, and Zeuka di Treppo. The trees were 12 years old and were grown in organic orchards in Lavariano and Carnia, two areas of the Friuli-Venezia Giulia region, in northeastern Italy. Samples were collected in two different periods of 2002: in May, when the diseased trees had only slight symptoms, and in September, when typical symptoms were evident.

For each cultivar, leaves of five healthy trees (asymptomatic since planting), five APP-infected trees (symptomatic for at least 
3 years), and five recovered trees (APP-diseased but asymptmatic for at least the last 3 years) were chosen for ultrastructural and biochemical analyses. To confirm the presence or absence of phytoplasmas in randomly sampled leaf and root tissues, samples were tested by immunofluorescence (17) and by polymerase chain reaction (PCR).

A phytoplasma enrichment procedure (1) was used to extract DNA from $1.0 \mathrm{~g}$ of fresh material; 35 cycles of PCR with $\mathrm{f} 01 / \mathrm{r} 01$ primers were carried out under the following conditions: $30 \mathrm{~s}$ of denaturation at $95^{\circ} \mathrm{C}, 75 \mathrm{~s}$ of annealing at $55^{\circ} \mathrm{C}$, and $90 \mathrm{~s}$ of extension at $72^{\circ} \mathrm{C}(18)$. Amplification products were analyzed by direct agarose gel electrophoresis.

Transmission electron microscopy. The cytochemical method developed for the localization of $\mathrm{H}_{2} \mathrm{O}_{2}$ in plant tissues was carried out as described by Bestwick et al. (2).

Small samples of leaves $(1 \times 3 \mathrm{~mm})$ and roots $(3 \mathrm{~mm}$ long $)$ collected from healthy, APP-infected, and recovered apple trees were incubated in freshly prepared $5 \mathrm{mM} \mathrm{CeCl}_{3}$ in $50 \mathrm{mM} \mathrm{3}-(\mathrm{N}$-morpholino)propanesulfonic acid at $\mathrm{pH} 7.2$ for $1 \mathrm{~h}$. Tissues were then fixed in a mixture of $1.25 \%$ ( $\mathrm{vol} / \mathrm{vol}$ ) glutaraldehyde and $1.25 \%$ (vol/vol) paraformaldehyde in $0.1 \mathrm{M}$ phosphate buffer at $\mathrm{pH} 7.2$ for $1 \mathrm{~h}$. After fixation, samples were washed in buffer, dehydrated in ethanol, and then embedded in Epon/Araldite. Several serial ultrathin sections of at least 80 samples from each group (healthy, APP-infected, and recovered trees) were stained with lead citrate and uranyl acetate and then observed under a Philips CM 10 transmission electron microscope (TEM) operated at $80 \mathrm{kV}$.

Reduced glutathione. Leaf samples (200 mg for each extract, from healthy, recovered, and APP-infected leaves) were homogenized in a mortar, in ice-cold 5\% (wt/vol) 5-sulfosalicylic acid containing $6.3 \mathrm{mM}$ diethylenetriamine pentaacetic acid, as described by De Knecht et al. (6). After centrifugation at $10,000 \times g$ for $10 \mathrm{~min}$ at $4^{\circ} \mathrm{C}$, the supernatant fraction of the extracts was filtered through a Micropure $0.45-\mu \mathrm{m}$ filter (Amicon, Danver, MA) and immediately assayed by high-performance liquid chromatography (Beckman, Fullerton, CA). GSH was separated through a reverse-phase $\mathrm{C}_{18}$ column (Purosphere, Merck, Darmstadt, Germany) injected with $200 \mu \mathrm{l}$ of the filtered supernatant fraction. The GSH separation was obtained with isocratic flow of $2 \% \mathrm{CH}_{3} \mathrm{CN}$ and $98 \%$ water, at the rate of $0.7 \mathrm{ml} \mathrm{min}^{-1}$. The elution solution contained $0.05 \%$ trifluoroacetic acid. The GSH content was determined by postcolumn derivatization with $300 \mu \mathrm{M}$ Ellman's reagent [5,5'-dithiobis(2-nitrobenzoic acid)], detected at $412 \mathrm{~nm}$, and measured by a calibration curve for standard $\mathrm{SH}$
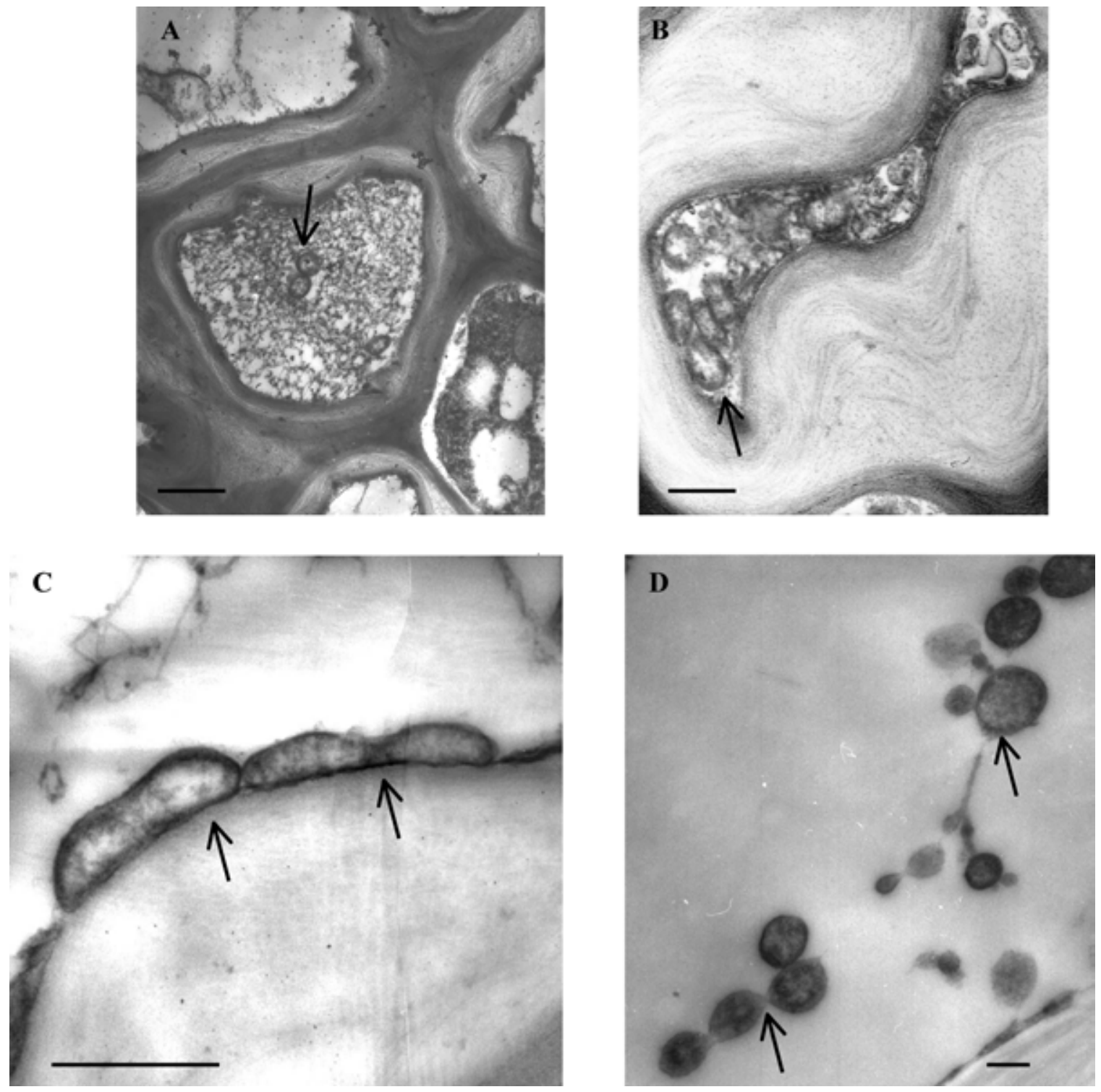

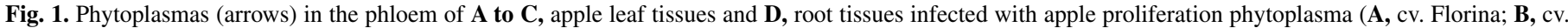

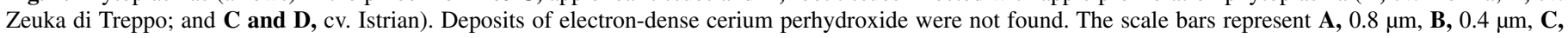
$1 \mu \mathrm{m}$, and $\mathbf{D}, 0.4 \mu \mathrm{m}$. 
groups. Identification of GSH was based on a comparison of its retention times with those of standard GSH (Merck).

Protein content, guaiacol peroxidase activity, and malondialdehyde assays. Leaf samples $(700 \mathrm{mg}$ for each extract, from healthy, recovered, and APP-infected leaves) assayed for protein content and GPX activity were shock-frozen in liquid nitrogen, homogenized on ice in the ratio of $1: 4(\mathrm{wt} / \mathrm{vol})$ with $50 \mathrm{mM}$ $\mathrm{K}_{2} \mathrm{HPO}_{4} / \mathrm{KH}_{2} \mathrm{PO}_{4}$ buffer, $\mathrm{pH} 7.0$, containing $5 \mathrm{mM}$ sodium ascorbate, $0.2 \mathrm{mM} \mathrm{Na}_{2}$-EDTA, $1 \%$ (wt/vol) polyvinylpyrrolidone, and $1 \%(\mathrm{vol} / \mathrm{vol})$ Triton X-100. Each homogenate, after gauze filtration, was centrifuged at $10,000 \times g$ for $25 \mathrm{~min}$ at $4^{\circ} \mathrm{C}$. Protein concentration in the resulting supernatant was determined by the BioRad protein assay (Bio-Rad, Munich), using bovine serum albumin as a standard, mainly as described by Bradford (5). GPX activity in the supernatants was measured with a Varian Cary 1E spectrophotometer and expressed as $\Delta A_{470} \mathrm{~min}^{-1} \mathrm{mg}^{-1}$ of protein (23).

Leaf samples ( $1 \mathrm{~g}$ for each extract, from healthy, recovered, and APP-infected leaves) for MDA analysis were homogenized in $0.1 \%$ (wt/vol) trichloroacetic acid, gauze-filtered, and centrifuged at $10,000 \times g$ for $10 \mathrm{~min}$. The supernatant was treated with $0.5 \%$ 2-thiobarbituric acid in $20 \%$ trichloroacetic acid, in the ratio of $1: 4(\mathrm{vol} / \mathrm{vol})(10)$. The mixture was incubated at $95^{\circ} \mathrm{C}$ for $25 \mathrm{~min}$, quickly cooled on ice, and then centrifuged as described above. The MDA content of the supernatants was determined with a Varian Cary $1 \mathrm{E}$ spectrophotometer at $\left(A_{532}-\right.$ $\left.A_{600}\right)$, using an extinction coefficient of $155 \mathrm{mM} \mathrm{cm}^{-1}$.

Statistics. For each cultivar, five healthy, five APP-infected, and five recovered trees were chosen for ultrastructural and biochemical analyses. All experiments were carried out in at least three replicates using materials that were homogeneous in their general aspect, size, and symptoms. We evaluated the significance of the experimental results, where appropriate, using the unpaired $t$ test (SigmaPlot 8.0). Data are expressed as the mean \pm SE of at least three independent measurements.

\section{RESULTS}

Phytoplasma detection. PCR analysis amplified DNA of APP from leaves and roots of all symptomatic apple trees, while no DNA amplification was obtained from healthy plant material. In
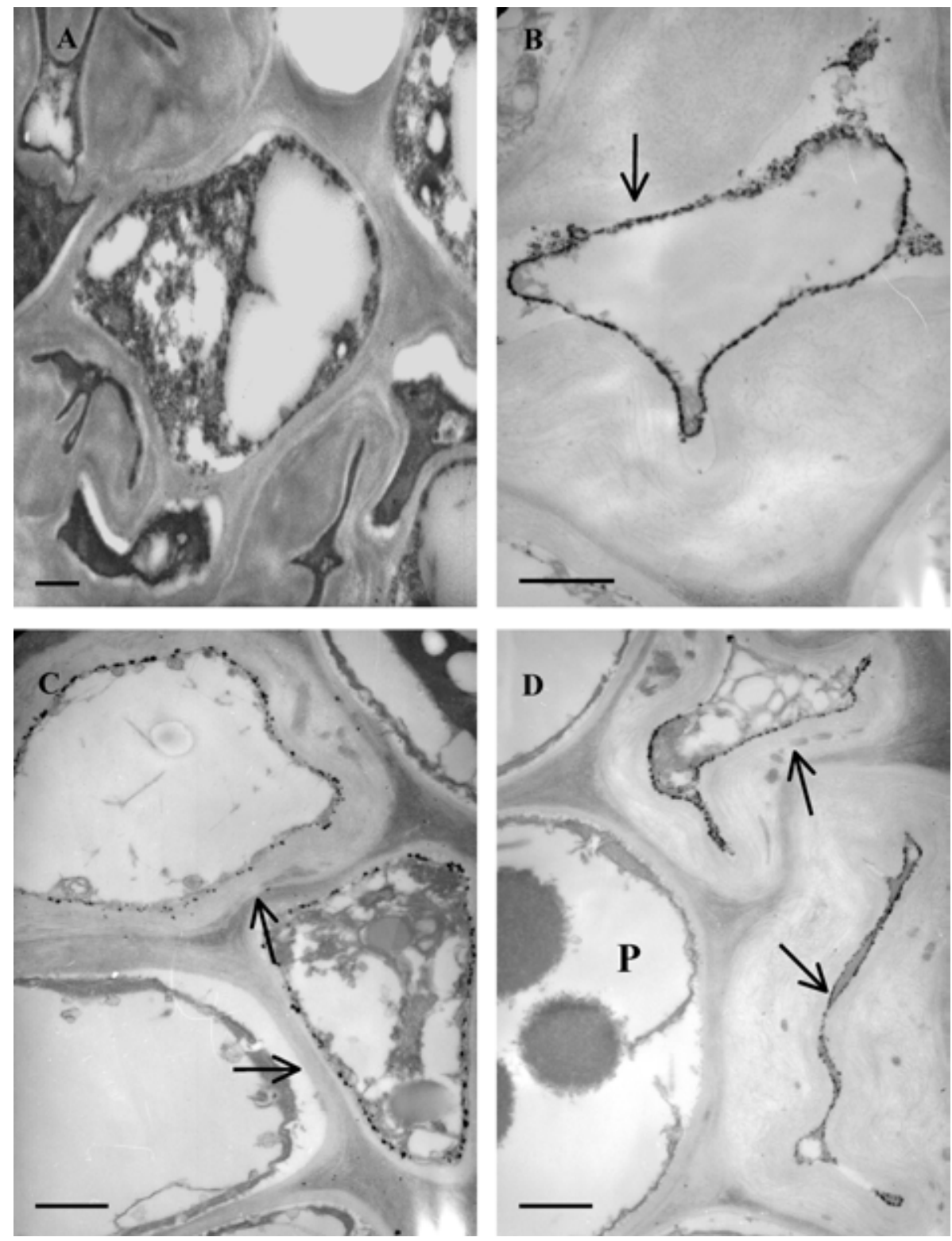

Fig. 2. A, Micrograph of healthy leaf tissue of apple cv. Florina. Precipitates of cerium perhydroxide, indicating the presence of $\mathrm{H}_{2} \mathrm{O}_{2}$, were not observed in the phloem, and phytoplasmas were not present. B, C, and D, Micrographs of phloem cells of leaf tissue from recovered apple trees (B, cv. Florina; C, cv. Zeuka di Treppo; and D, cv. Istrian). Phytoplasmas were not present; cerium perhydroxide precipitates were localized in leaf tissue on the plasmalemma of sieve tubes (arrows). No precipitates were found in parenchymal cells $(\mathrm{P})$. All scale bars represent $1 \mu \mathrm{m}$. 
recovered trees, we obtained amplification of APP DNA only from root samples, and not from leaves (data not shown). These results were confirmed by immunofluorescence analyses.

Transmission electron microscopy. In all APP-infected trees, we observed phytoplasmas in the phloem of leaves (Fig. 1A to C) and roots (Fig. 1D). The presence of the pathogen was not easy to demonstrate in any of the cultivars, because the sieve tubes had often collapsed. We did not observe any deposits of electrondense cerium perhydroxide (indicating the presence of $\mathrm{H}_{2} \mathrm{O}_{2}$ ) in infected tissues of leaves and roots.

We did not observe precipitates of electron-dense cerium perhydroxide in healthy (never diseased) leaves and roots of trees of all three cultivars (Fig. 2A). Cellular morphology and organelles were well preserved, and phytoplasmas were not observed. In recovered apple trees of all the cultivars, we observed phytoplasmas only in the phloem of the roots (data not shown), not in leaf tissues.

TEM observations of tissues from recovered trees revealed that cerium perhydroxide accumulated only in the plasmalemma of sieve tubes of leaves (Fig. 2B to D). We did not find precipitates in the companion cells, parenchyma tissue (Fig. 2D), or root tissues (data not shown).

We did not detect ultrastructural differences between material collected in the spring and material collected in the fall.

Protein content and oxidative status in leaves. The protein contents of leaves from healthy, recovered, and APP-infected trees of the same cultivar were not significantly different from

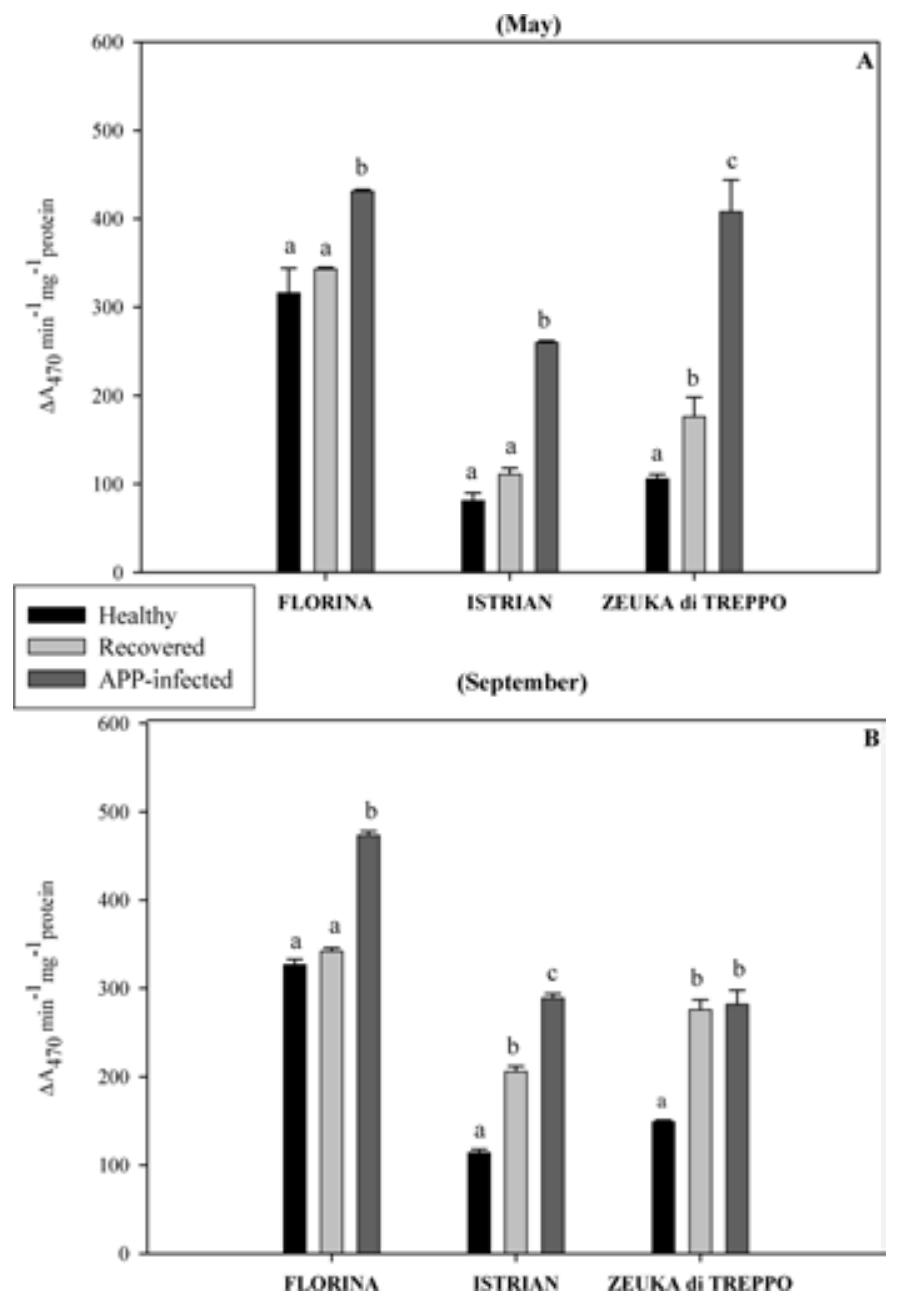

Fig. 3. Guaiacol peroxidase activity in leaves of three apple cultivars, from healthy trees, trees infected by apple proliferation phytoplasma (APP), and trees that had recovered from the infection, collected in A, May and $\mathbf{B}$, September 2002. Different letters for the same cultivar denote significant differences at $P \leq 0.05 ; n=3$; the error bars represent the standard error. one another (data not shown). However, GPX activity was recorded at significantly different levels in leaves of healthy, recovered, and APP-infected trees, both in May and in September (Fig. 3A and B). The GPX activity detected in all cultivars at both sample dates had the following trend: APP-infected trees $\geq$ recovered trees $\geq$ healthy trees.

In contrast, GSH content in leaves followed this trend: healthy trees $\geq$ recovered trees $>$ APP-infected trees in five of the six cultivar-date combinations (Fig. 4A and B); however, the differences between the three groups of trees were statistically significant $(P \leq 0.05)$ only for $\mathrm{cv}$. Istrian.

We did not observe large differences in the MDA contents of healthy, recovered, and APP-infected leaves of the same cultivar collected in May (Fig. 5A and B). The greatest differences occurred in September, when all cultivars showed the trend of higher levels of MDA in recovered than APP-symptomatic or healthy leaves; these differences were significant for two of the three cultivars.

\section{DISCUSSION}

Serological and PCR analyses indicated the distribution of APP in symptomatic and recovered apple trees, showing that all the symptomatic apple trees were infected in the canopy and in the roots and that recovered trees were infected only in the roots, as previously reported by Loi et al. (16).

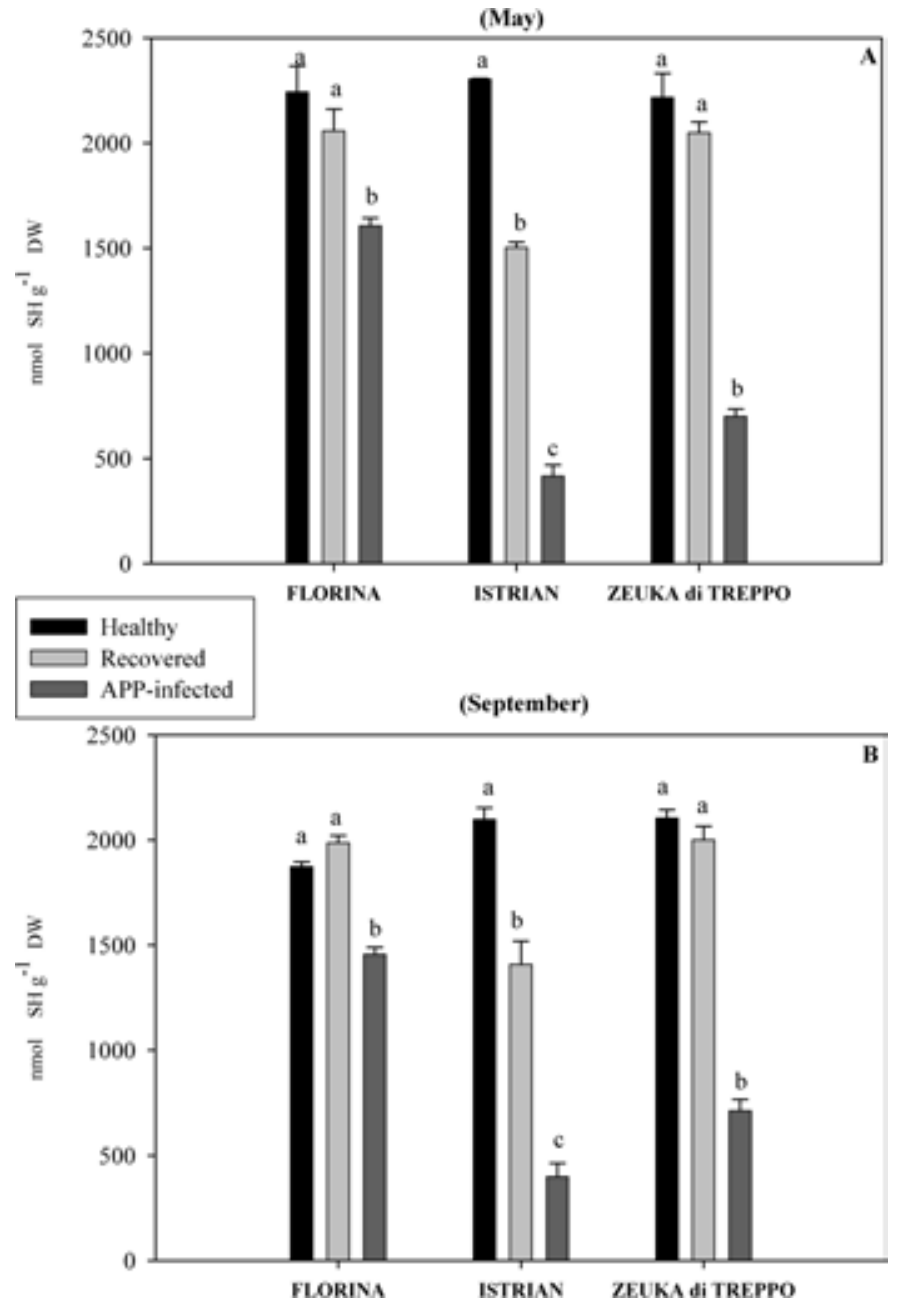

Fig. 4. Reduced glutathione in leaves of three apple cultivars, from healthy trees, trees infected by apple proliferation phytoplasma (APP), and trees that had recovered from the infection, collected in A, May and B, September 2002. Different letters for the same cultivar denote significant differences at $P \leq 0.05 ; n=3$; the error bars represent the standard error. 
TEM observations of root and leaf tissues from both healthy and APP-infected apple trees found no cerium perhydroxide labeling, indicating the absence of detectable $\mathrm{H}_{2} \mathrm{O}_{2}$. The labeling was present only in recovered trees and was localized in the leaf phloem but not in the roots, where phytoplasmas were still present. These results were the same for all samples of the three cultivars, whether collected in May or in September.

$\mathrm{H}_{2} \mathrm{O}_{2}$ is produced by plant cells in response to pathogen attack (3). It has been reported that $\mathrm{H}_{2} \mathrm{O}_{2}$ strongly inhibits fungal activity and spore germination of Peronospora tabacina, Cladosporium cucumerinum, and Colletotrichum lagenarium grown in vitro and on tobacco leaves (24); $\mathrm{H}_{2} \mathrm{O}_{2}$ inhibited the germination of sporangiospores of $P$. tabacina grown in vitro and the development of blue mold disease on tobacco leaf disks, functioning as an antifungal agent in disease resistance (26). Moreover, other studies have shown that $\mathrm{H}_{2} \mathrm{O}_{2}$ treatment induces salicylic acid accumulation in plants (14), suggesting that $\mathrm{H}_{2} \mathrm{O}_{2}$ affects the induction of the expression of systemic acquired resistance genes (20). It has also been reported that systemic acquired resistance generally means resistance against symptom expression and not necessarily against pathogens (8).

$\mathrm{H}_{2} \mathrm{O}_{2}$ plays a central role in the oxidative burst, acting as a signal for the localized death of challenged cells during the hypersensitive reaction (19) and as a diffusible signal for the induction
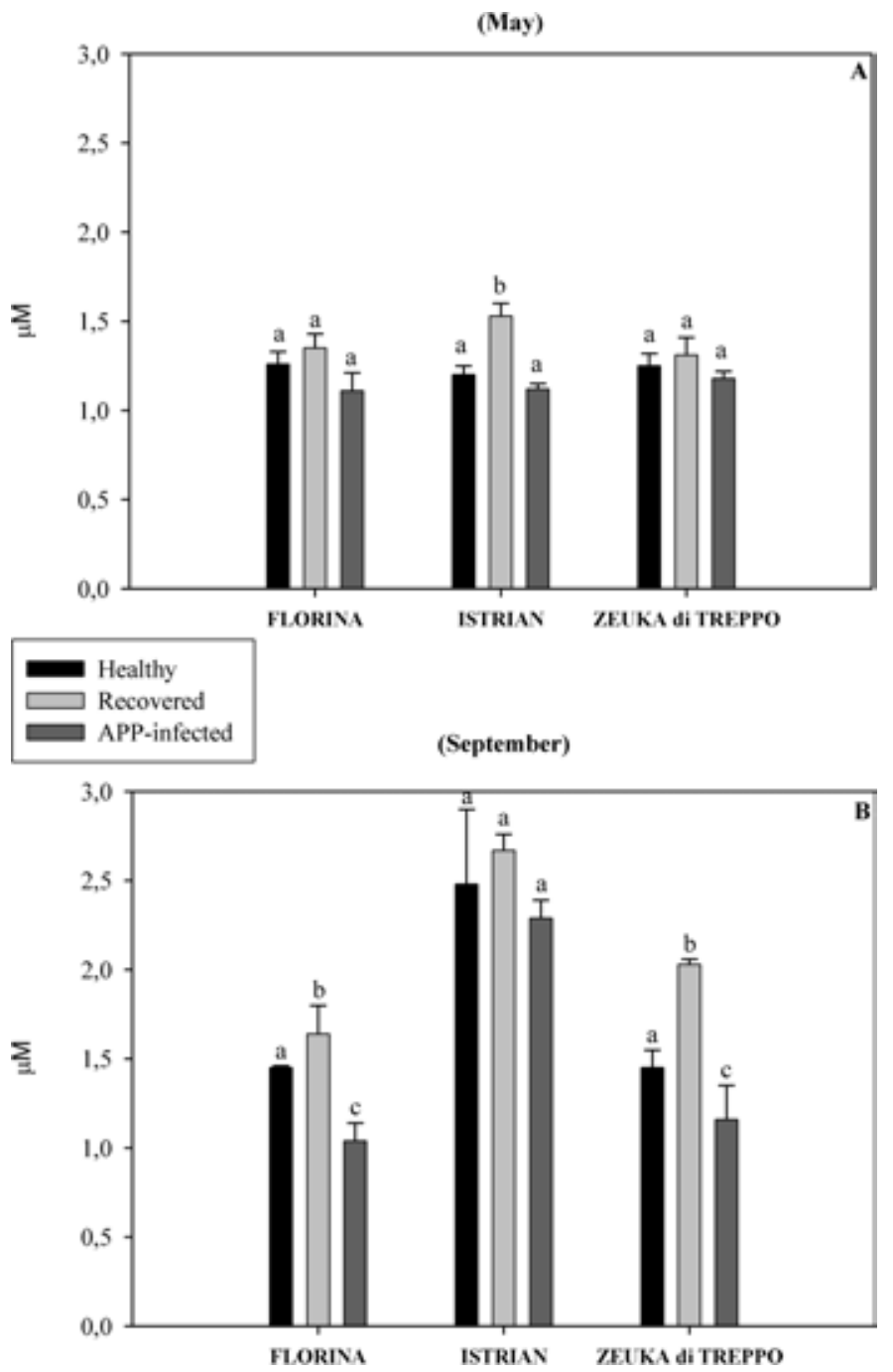

Fig. 5. Malondialdehyde concentration in leaves of three apple cultivars, from healthy trees, trees infected by apple proliferation phytoplasma (APP), and trees that had recovered from the infection, collected in A, May and $\mathbf{B}$, September 2002. Different letters for the same cultivar denote significant differences at $P \leq 0.05 ; n=3$; the error bars represent the standard error. of cellular protective genes in adjacent healthy cells and tissues (15). Therefore, it is possible that all these defense mechanisms contribute to the recovery phenomenon.

We hypothesize that $\mathrm{H}_{2} \mathrm{O}_{2}$ accumulation in the leaf phloem could be an endogenous factor that helps to explain why the phytoplasmas are not present in the canopy of recovered apple trees; $\mathrm{H}_{2} \mathrm{O}_{2}$ could impede the spread and replication of phytoplasmas in leaves, inhibiting the pathogen directly or by generating other reactive free radicals with antimicrobial activity.

On the other hand, Loi and co-workers (16) reported experimental transmission of APP from recovered trees to healthy ones by root grafting in $97 \%$ of their trials. Thus phytoplasmas in root tissues of recovered trees are viable and infectious.

Finally, some important differences between $\mathrm{H}_{2} \mathrm{O}_{2}$ accumulation in recovered plants and the oxidative burst must be emphasized. The oxidative burst is a rapid and transient production of a large amount of ROS in tissues, in response to invasion by a pathogen. In recovered apple trees $\mathrm{H}_{2} \mathrm{O}_{2}$ production is associated with the disappearance of phytoplasmas and the associated symptoms in leaves of trees that had been infected and symptomatic: $\mathrm{H}_{2} \mathrm{O}_{2}$ is not detectable at the first stages of infection and during the symptomatic period, but only when recovery occurs. Moreover, in recovered trees the $\mathrm{H}_{2} \mathrm{O}_{2}$ that accumulates in tissues is not rapidly removed, as it is during oxidative burst.

We hypothesize that the recovery phenomenon relies on an overproduction of $\mathrm{H}_{2} \mathrm{O}_{2}$, which counteracts pathogen virulence. This overproduction does not occur either in healthy (never infected) leaves or in APP-infected leaves, but possibly for opposite reasons: the healthy leaves have no oxidative stress and thus have a lower ROS content than APP-infected leaves, in which $\mathrm{H}_{2} \mathrm{O}_{2}$ production is efficaciously "quenched" and counterbalanced by the induction of GPX activity. Similarly, the ROS production in APP-infected leaves could be counteracted by the oxidation of GSH to GSSG, whereas no depletion of GSH occurs in healthy leaves, because of their presumably low ROS content. Thus, only in leaves of recovered trees-with insufficient GPX induction and less oxidation of GSH to GSSG than in APP-infected leavesdoes the ROS level appear to be sufficiently high (as shown by the presence of abundant $\mathrm{H}_{2} \mathrm{O}_{2}$ in tissues) to counteract pathogen virulence.

The presence of high levels of $\mathrm{H}_{2} \mathrm{O}_{2}$ in recovered leaves, together with a relatively low level of antioxidants (such as GPX and GSH) may also explain elevated MDA content often detected in recovered leaves, compared to healthy and APP-infected ones; MDA levels were highest in September, when the symptoms were fully evident.

In conclusion, our data show that some components of the oxidant-scavenging system are not very active in leaves of recovered plants. We propose that the oxidative stress in this material is not effectively counteracted, leading to an overproduction of $\mathrm{H}_{2} \mathrm{O}_{2}$, which aids in lessening symptom severity.

\section{ACKNOWLEDGMENTS}

This research was supported by funds from MIUR 2002, Italy. We thank Z. Vattuone and A. Vecchione for their technical assistance during sample preparation.

\section{LITERATURE CITED}

1. Ahrens, U., and Seemüller, E. 1992. Detection of DNA of plant pathogenic mycoplasmalike organisms by a polymerase chain reaction that amplifies a sequence of the $16 \mathrm{~S}$ rRNA gene. Phytopathology 82: 828-832

2. Bestwick, C. S., Bennett, M. H., and Mansfield, J. W. 1995. Hrp mutant of Pseudomonas syringae pv. phaseolicola induces cell wall alterations but not membrane damage leading to the HR in lettuce (Lactuca sativa). Plant Physiol. 108:503-516.

3. Baker, C. J., and Orlandi, E. W. 1995. Active oxygen in plant pathogenesis. Annu. Rev. Phytopathol. 33:299-321. 
4. Bolwell, G. P., Butt, V. S., Davies, D. R., and Zimmerlin, A. 1995. The origin of oxidative burst in plants. Free Radical Res. 23:517-532.

5. Bradford, M. M. 1976. A rapid and sensitive method for the quantitation of microgram quantities of protein utilizing the principle of protein-dye binding. Anal. Biochem. 72:248-254.

6. De Knecht, J. A., Van Dillen, M., Koevoets, P. L. M., Schat, H., Verkleji, J. A. C., Ernst, W. H. O. 1994. Phytochelatins in cadmium-sensitive and cadmium-tolerant Silene vulgaris: Chain length distribution and sulphide incorporation. Plant Physiol. 104:255-261.

7. Esterbauer, H. 1982. Aldehyde products of lipid peroxidation. Pages 101128 in: Free Radicals Lipid Peroxidation and Cancer. D. McBrien and T. Slater, eds. Academic Press, Boca Raton, FL.

8. Fodor, J., Gullner, G., Ádám, A. L., Barna, B., Koomíves, T., and Király, Z. 1997. Local and systemic responses of antioxidants to tobacco mosaic virus infection and to salicylic acid in tobacco. Plant Physiol. 114:1443-1451.

9. Halliwell, B., and Gutteridge, J. M. C. 1989. Pages 277-289 in: Free Radicals in Biology and Medicine. Clarendon Press, Oxford.

10. Heat, R. L., and Packer, L. 1968. Photoperoxidation in isolated chloroplasts. I. Kinetics and stoichiometry of fatty acid peroxidation. Arch. Biochem. Biophys. 25:189-198.

11. Kaminska, M., and Zawadska, B. 1973. Studies on apple proliferation in Poland. III. Observations on the disappearance of apple proliferation symptoms. Acta Agrobot. 26:97-101.

12. Kunze, L. 1976. The effect of different strains of apple proliferation on the growth and crop of infected trees. Mitt. Biol. Bundesanst. LandFortwirtsch. Berlin-Dahlem 170:107-115.

13. Lamb, C., and Dixon, R. A. 1997. The oxidative burst in plant disease resistance. Annu. Rev. Plant Physiol. Plant Mol. Biol. 48:251-275.

14. León, J., Lawton, M. A., and Raskin, I. 1995. Hydrogen peroxide stimulates salicylic acid biosynthesis in tobacco. Plant Physiol. 108:1673-1678.

15. Levine, A., Tenhaken, R., Dixon, R., and Lamb, C. $1994 . \mathrm{H}_{2} \mathrm{O}_{2}$ from the oxidative burst orchestrates the plant hypersensitive disease resistance response. Cell 79:583-593.

16. Loi, N., Ermacora, P., Ferrini, F., Carraro, L., and Osler, R. 2002. Trasmissione sperimentale del fitoplasma degli scopazzi del melo da piante "recovered" e sintomatiche di melo. Petria 12:373-374.
17. Loi, N., Ermacora, P., Carraro, L., Osler, R., and Chen, T. A. 2002. Production of monoclonal antibodies against apple proliferation phytoplasma and their use in serological detection. Eur. J. Plant Pathol. 108:81-86.

18. Lorenz, K.-H., Schneider, B., Ahrens, U., and Seemüller, E. 1995. Detection of the apple proliferation and pear decline phytoplasmas by PCR amplification of ribosomal and nonribosomal DNA. Phytopathology 85:771-776.

19. Martinez, C., Baccou, J. C., Bresson, C., Baissac, Y., Daniel, J. F., Jalloul, A., Montillet, J. L., Geiger, J. P., Assigbetsé, K., and Nicole, M. 2000. Salicylic acid mediated by the oxidative burst is a key molecule in local and systemic responses of cotton challenged by an avirulent race of Xanthomonas campestris pv. malvacearum. Plant Physiol. 122:757-766.

20. Neuenschwander, U., Vernooij, B., Friedrich, L., Uknes, S., Kessmann, H., Ryals, J. 1995. Is hydrogen peroxide a second messenger of salicylic acid in systemic acquired resistance? Plant J. 8:227-233.

21. Osler, R., Carraro L., Loi, N., and Refatti, E. 1993. Symptom expression and disease occurrence of a yellows disease of grapevine in northeastern Italy. Plant Dis. 77:496-498.

22. Osler, R., Loi, N., Carraro, L., Ermacora, P., and Refatti, E. 1999. Recovery in plants affected by phytoplasmas. Pages 589-592 in: Proc. Congr. Eur. Found. Plant Pathol., 5th.

23. Pandolfini, T., Gabbrielli, R., and Comparini, C. 1992. Nickel toxicity and peroxidase activity in seedlings of Triticum aestivum L. Plant Cell Environ. 15:719-725.

24. Peng, M., and Kuc, J. 1992. Peroxidase-generated hydrogen peroxide as a source of antifungal activity in vitro and on tobacco leaf disks. Phytopathology 82:696-699.

25. Schmid, G. 1965. Five and more years of observations on the proliferation virus of apples in the field. Zast. Bilja 85-88:285-289.

26. Schmid, G. 1975. Prolonged observations on spread and behaviour of proliferation disease in apple orchards. Acta Hortic. 44:183-191.

27. Vera-Estrella, R., Blumwald, E., and Higgins, V. J. 1992. Effect of specific elicitors of Cladosporium fulvum on tomato suspension cells. Plant Physiol. 99:1208-1215.

28. Wojtaszek, P. 1997. The oxidative burst: A plant's early response against infections. Biochem. J. 322:681-692. 